\title{
Study of Oxo-biodegradable Polyethylene Degradation in Simulated Soil
}

\author{
Lucas Bonan Gomes ${ }^{a *}$, Jalma Maria Klein ${ }^{a}$, Rosmary Nichele Brandalise ${ }^{b}$, \\ Mara Zeni ${ }^{b}$ Barbara Catarina Zoppas ${ }^{b}$, Ana Maria Coulon Grisa ${ }^{b}$ \\ ${ }^{a}$ Universidade Federal do Rio Grande do Sul - UFRGS, Avenida Osvaldo Aranha, 99, \\ sala 705C, CEP 90035-190, Porto Alegre, RS, Brazil \\ ${ }^{b}$ Universidade de Caxias do Sul-UCS, Rua Francisco Getúlio Vargas, 1130, \\ CEP 95070-560, Caxias do Sul, RS, Brazil
}

Received: June 27, 2013; Revised: June 23, 2014

\begin{abstract}
This study aims to evaluate the influence of pro-oxidant additive and accelerated aging on the degradation of polyethylene (PE) samples in simulated soil, in accordance with ASTM G160-03. Films of polyethylene with and without pro-oxidant additive were studied, before and after 72 hours of accelerated aging. The films were initially characterized by analyses of Scanning Electron Microscopy (SEM) and Fourier Transform Infrared Spectroscopy (FTIR) (to evaluate the Carbonyl Index (CI)). The films were exposed for 30, 60 and 90 days in simulated soil, with controlled moisture and soil $\mathrm{pH}$. The results showed the degradation of polyethylene films through an increase of CI in samples with additive and accelerated aging after 30 days of exposure, and a decrease, after 60 and 90 days, indicating the uptake of material oxidation by-products by microorganisms. The polyethylene films without pro-oxidant additive after accelerated aging showed greater structural and surface modifications, as compared to films with the additive.
\end{abstract}

Keywords: accelerated aging, biodegradation, microorganisms, polyethylene, pro-oxidant additives

\section{Introduction}

During the last decades, has increased the necessity in the search for solutions to minimize environmental problems caused by polymeric materials, especially polyolefins such as polyethylene and polypropylene, when disposed in an appropriate environment ${ }^{1}$. Researches have been conducted on direct incorporation of carbonyl groups within the backbone or its in situ generation by introduction of prooxidant at the processing stage, to allow different lifetimes or induction time for polymeric materials after disposal ${ }^{2}$.

The oxidative degradation of the polyethylene containing pro-oxidant additives can be accelerated by ultraviolet (UV) light (photodegradation) or by thermal degradation using heat over time ${ }^{3}$. Typical pro-oxidants include UV activators like aromatic ketones and/or transition metal based complexes ${ }^{2,3}$. Initial abiotic oxidation is an important stage as it determines the rate of the entire process. In this stage the incorporation of oxygen into the carbon chain polymer backbone results in the formation of functional groups such as carboxylic or hydro-carboxylic acids, esters as well as aldehydes and alcohols ${ }^{3-7}$.

Every year, about 140 million tons of synthetic polymers are produced and $30 \%$ of this amount is used as packing ${ }^{8,9}$. In Brazil, the polyethylene contributes with $48.9 \%$ of all the thermoplastic polymers discarded ${ }^{10}$. It is used, in its various forms, in the manufacture of plastic bags and of packaging of various products. These products require a long time

*e-mail: lucas.gomes@ufrgs.br to decompose after discard ${ }^{10-12}$. In order to minimize the generation of urban wastes that is inert to degradation, it stands the development of polymers of short duration, those with the possibility of having their degradation process accelerated with the incorporation of pro-oxidant additives ${ }^{13}$.

There has been extensive research into biodegradability of polyolefins containing pro-oxidants in the presence of microbial consortium present in the environment as well as selected microbial species in defined medium under controlled laboratory conditions $\mathrm{s}^{14-17}$. Koutny et al. ${ }^{18}$ reported that several members of Rhodococcus genus proving their role in the interaction of pre-oxidized PE, formed biofilms on the surface of oxidized low-density polyethylene film containing pro-oxidant additives, thus suggesting their role in assimilation of oxidized polyethylene film. Fontanella et al. ${ }^{19}$ compared the biodegradability of various polyethylene films with a balanced content of antioxidants and pro-oxidants (manganese + iron or manganese + iron + cobalt) inoculated with the strain Rhodococcus rhodochrous in mineral medium, during 180 days. The results show that the main factor controlling the biodegradability of the PE films is the nature of the pro-oxidant additive and to a lesser extent that of the matrix. Except for the samples containing very high content of cobalt additive, the various polymer films were used as substrates by the bacteria. Albertsson et al. ${ }^{20}$ studied the biotic degradation of pro-oxidized samples lowdensity polyethylene containing starch and pro-oxidant. Pro-oxidized samples were subjected to aqueous sterile and 
aqueous biotic (Arthrobacter paraffineus) environments at ambient temperatures for 3.5 years. Carboxylic acids were identified in the abiotically degraded samples in contrast to the biotic environment, where assimilation of lower molecular weight products by bacterium, especially carboxylic acids, had taken place as determined by gas chromatography and gas chromatography-mass spectrometry. Similar results were reported by YamadaOnodera et al. ${ }^{21}$, where the functional groups inserted into pro-oxidized PE samples aided biodegradation and suggested that microorganisms might even have a role to play during degradation of polyethylene samples. However, such experiments do not simulate real-time exposure conditions where a complex microbial community is present and variable abiotic and biotic factors influence the biodegradability of polyethylene. Thus, the standard ASTM G160-03 22 , used in this study, aims to evaluate the biotic degradation of pro-oxidized samples polyethylene containing pro-oxidant additive exposed in simulated soil during 90 days and identify a complex microbial community present in the soil after exposure.

\section{Material and Methods}

The blue polymeric films $(25 \mu \mathrm{m})$ with and without pro-oxidant additive $\left(\mathrm{PE}_{\mathrm{Ox}}\right.$ and $\left.\mathrm{PE}\right)$, respectively, were made by commercial grade of the high-density polyethylene (HDPE), and linear low-density polyethylene (LLDPE), with a ratio 60/40, from Braskem S.A., Brazil (Table 1). The melt flow index for HDPE is $0.35 \mathrm{~g} / 10 \mathrm{~min}\left(190{ }^{\circ} \mathrm{C} / 5 \mathrm{~kg}\right)$ according ASTM 1238-04c and, for LLDPE is $0.71 \mathrm{~g} / 10 \mathrm{~min}$ $\left(190{ }^{\circ} \mathrm{C}, 2.16 \mathrm{~kg}\right)$ according to ASTM $1238-04 \mathrm{c}$ and ASTM $\mathrm{D}-1505^{23,24}$. The films were manufactured in a single-screw extruder, 45-mm screw diameter, diameter ratio (L/D) of 30, and temperature profile of $142,195,195,183$, and $160{ }^{\circ} \mathrm{C}$.
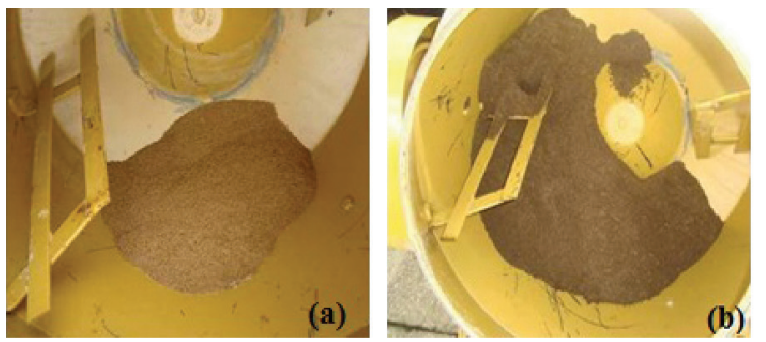

The blue pigment was acquired from Multicolor Indústria e Comércio de Pigmentos LTDA., MFI $25 \pm 3$ g.10 $\mathrm{min}^{-1}$, concentration of $18.6 \%$ and thermal resistance $260{ }^{\circ} \mathrm{C}$.

The accelerated aging test was carried out in a Weathering Tester equipment from Comexim Matérias Primas Indústria e Comércio Ltda., following an adapted ASTM G154-00 method ${ }^{25}$ with fluorescent lamps (Philips TL 40W), which emit light with a wavelength of $313 \mathrm{~nm}$. The chamber repeats continuously the following cycle: a 4-h period of UV irradiation at $60^{\circ} \mathrm{C}$ followed by a 4-h period of de-ionized water spray (steam condensation) at $40{ }^{\circ} \mathrm{C}$. The samples $\mathrm{PE}_{\mathrm{OX}}$ and $\mathrm{PE}$ were submitted to the aging process for period of 72 hours.

The simulated soil, which was used to assess the degradation of the polymer samples by the action of microorganisms, has been developed in accordance with ASTM G160-03 standard ${ }^{22}$. Each part of the simulated soil, black earth, grit sand and horse manure was mixed for 20 minutes with the aid a Horbach concrete mixer (Figure 1). After, the polymer samples were buried in polypropylene (PP) cups and placed in greenhouse according Figure 2.

After 30, 60 and 90 days of exposure in simulated soil, polymer samples were removed and washed in distilled water. The liquid from the washing process was centrifuged for 10 minutes in a centrifuge Fanem - Baby I Model 206 BL, at $1500 \mathrm{rpm}$. The supernatant was discarded and $0.1 \mathrm{~mL}$ of the sediment was inoculated with a platinum spatula on Sabouraud agar and incubated at $25^{\circ} \mathrm{C}$ for seven days in a

Table 1. Formulation of polymeric films.

\begin{tabular}{lcccc}
\hline Sample & $\begin{array}{c}\text { HDPE } \\
(\boldsymbol{\%} \mathbf{w t})\end{array}$ & $\begin{array}{c}\text { LLDPE } \\
(\boldsymbol{\%} \mathbf{w t})\end{array}$ & $\begin{array}{c}\text { Pigment } \\
(\boldsymbol{\%} \mathbf{w t})\end{array}$ & $\begin{array}{c}\text { Additive } \\
(\boldsymbol{\%} \mathbf{w t})\end{array}$ \\
\hline $\mathrm{PE}_{\mathrm{OX}}$ & 59.11 & 39.41 & 0.49 & 0.99 \\
$\mathrm{PE}$ & 59.70 & 39.80 & 0.50 & - \\
\hline
\end{tabular}
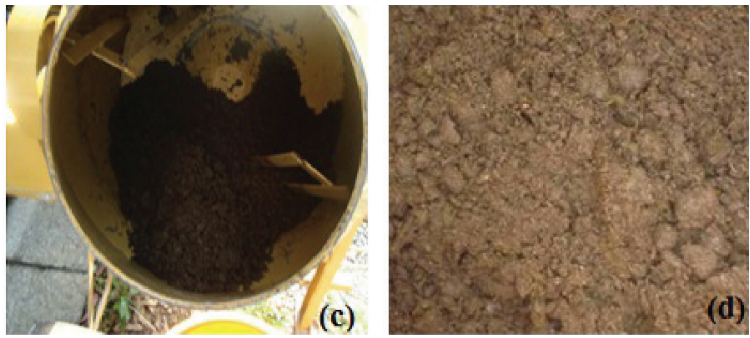

Figure 1. Simulated soil preparation: (a) grit sand, (b) grit sand and black earth, (c) grit sand, black earth and horse manure and (d) final aspect of simulated soil.
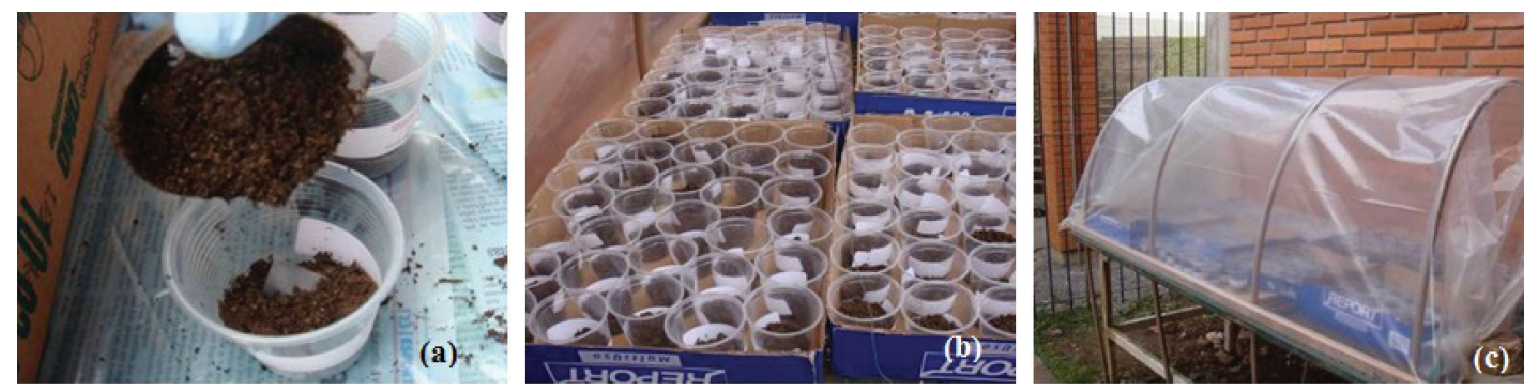

Figure 2. Exposure of samples in (a) cups with the simulated soil and the polymeric samples, (b) greenhouse dispose and (c) greenhouse. 
bacteriological culture incubator, model 502, Orion, Fanem. The identification of fungus presents in surface of polymers and simulated soil was performed by microscopic features with an Axiostar/Zeiss light microscope, magnification 400x. It was used as reference specific literature and taxons copies of the mycology collection of the Medical Mycology Laboratory of the Caxias do Sul University ${ }^{26,27}$.

The surface morphology of carbon covered samples before and after exposure simulated soil was observed using Scanning Electron Microscopy Shimadzu, SSX-550, Superscan at an accelerating voltage of $15 \mathrm{kV}$. The structural changes in the film due to both abiotic and biotic exposures were carried out in a Thermo Scientific Nicolet FT-IR spectrometer, model iS10. The spectra were obtained as an average of 32 scans with $4 \mathrm{~cm}^{-1}$ resolution. The carbonyl index (CI) was calculated from the ratio of the total area of the absorption band between 1700 to $1780 \mathrm{~cm}^{-1}$ (carbonyl peak) to the total area of the absorption band at $1463 \mathrm{~cm}^{-1}$ $\left(-\mathrm{CH}_{2}-\text { scissoring peak }\right)^{28}$.

\section{Results and Discussion}

The microbiological tests performed after exposure of samples in simulated soil allowed to identify the presence of several colonies of microorganisms such as: Geothrichum spp, Mucor spp, Rhizopus spp, Trichoderma spp, Aspergillus spp, and Aspergillus niger as well as nematodes and protozoa (Figure 3).

It can be seem in Figure 3 that the simulated soil provided an environment rich in various microorganisms, possibly because of the good initial conditions, that allowed the development of different microbial colonies, also observed in SEM analysis (Figure 4). The morphological analysis of polymer films shows some important aspects used to describe the phenomenon of biodegradation of polymers, such as biofilm ${ }^{29}$. In the samples of $\mathrm{PE}$ and $\mathrm{PE}_{\mathrm{OX}}$ exposed to simulated soil it was observed adherence and colonization of a complex mixture of microorganisms, surface erosion and presence of fruiting bodies and hyphae, characteristics that indicate the biodegradation of the polymer films (Figure 4).

A completely different pattern of microstructure is observed on SEM analysis of samples which were not submitted to simulated soil (Figure 5). No hyphae formation or a complex mixture of microorganism was observed, which proves that simulated soil combined with accelerating aging could change the entirely microstructure of the polymeric films.

FTIR spectra of $\mathrm{PE}$ and $\mathrm{PE}_{\mathrm{OX}}$ films before and after abiotic (accelerated aging) and biotic (simulated soil)
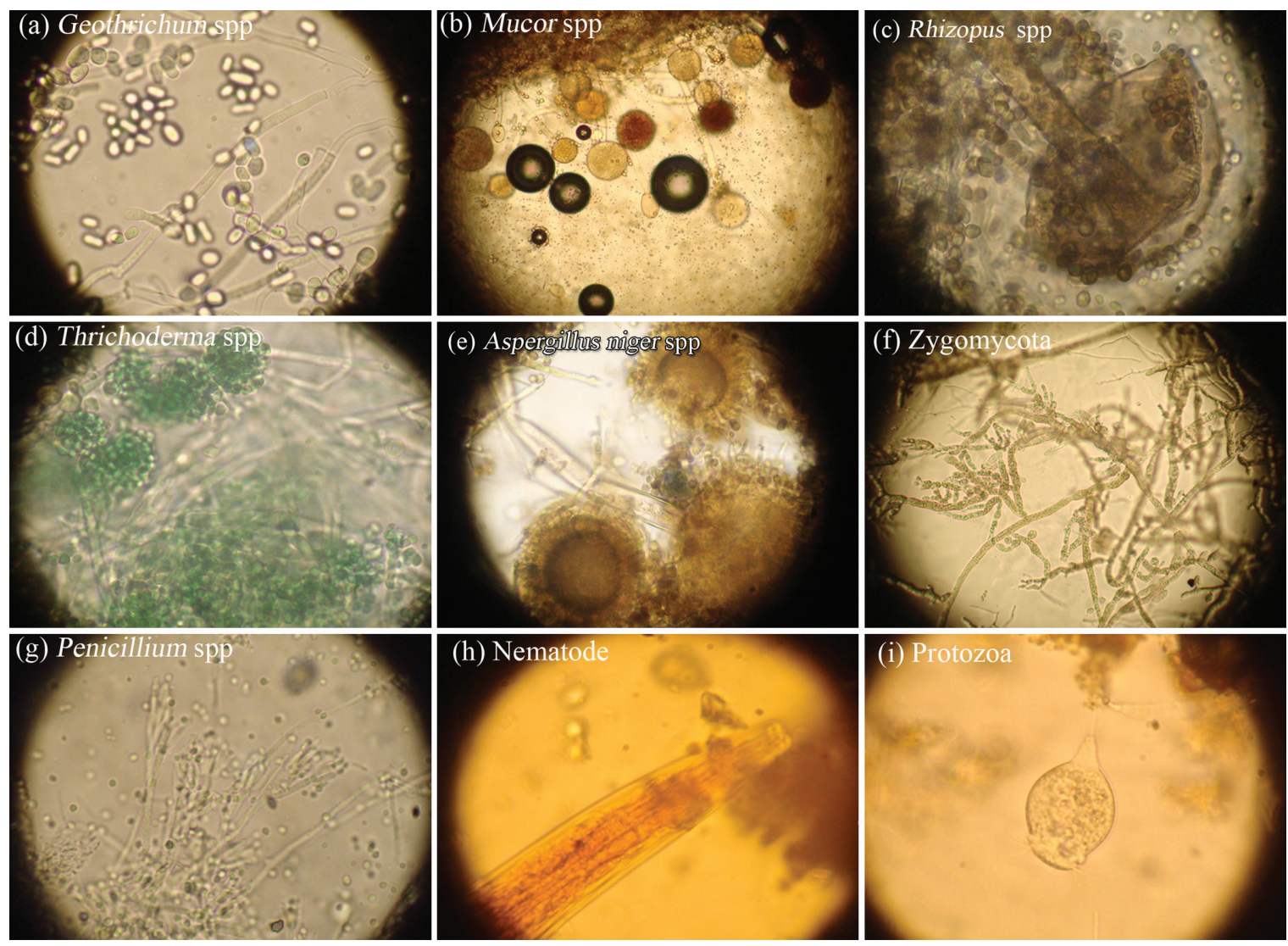

Figure 3. Microorganisms identify during exposure of polyethylene samples in simulated soil: (a) Geothrichum spp, (b) Mucor spp, (c) Rhizopus spp (d) Trichoderma spp, (e) Aspergillus niger spp, (f) Zygomycota, (g) Penicillium spp, (h) nematode and (i) protozoa. Magnification 400x. 

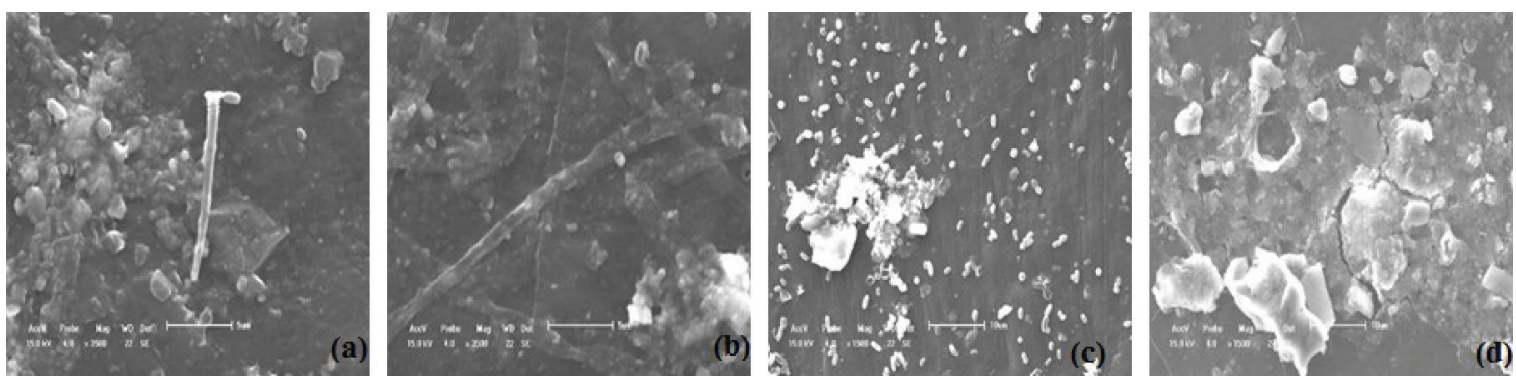

Figure 4. SEM micrographs of the surface of the $\mathrm{PE}$ and $\mathrm{PE}_{\mathrm{OX}}$ samples after simulated soil, (a) and (b), hyphae formation, (c) complex mixture of microorganism and (d) surface erosion.
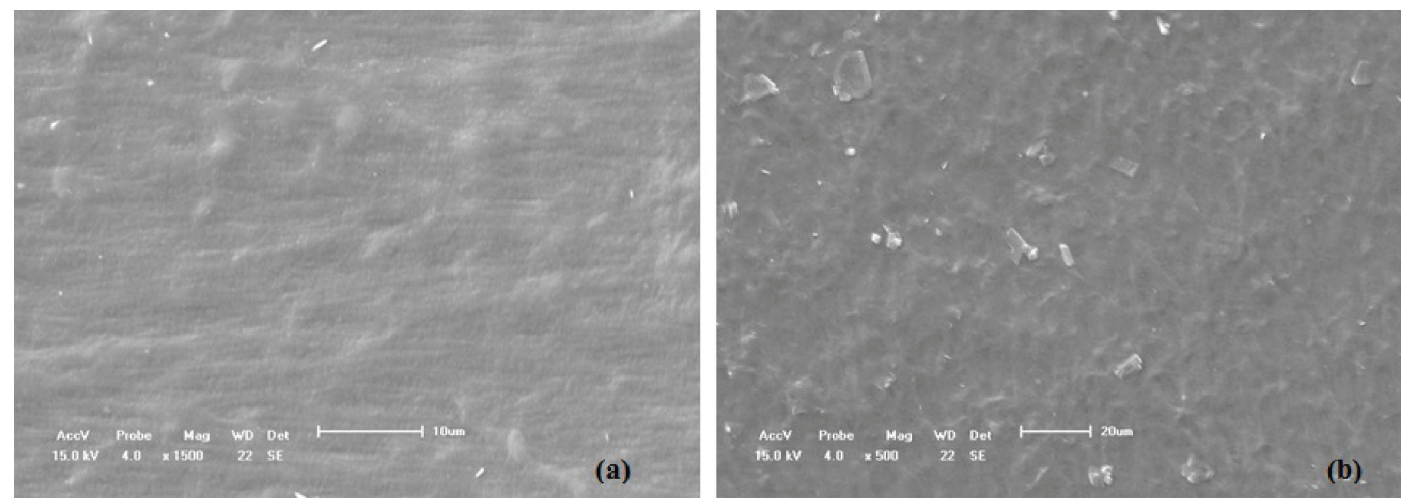

Figure 5. SEM micrographs of the surface of the $\mathrm{PE}(\mathrm{a})$ and $\mathrm{PE}_{\mathrm{OX}}$ (b) samples not submitted to simulated soil - control samples.

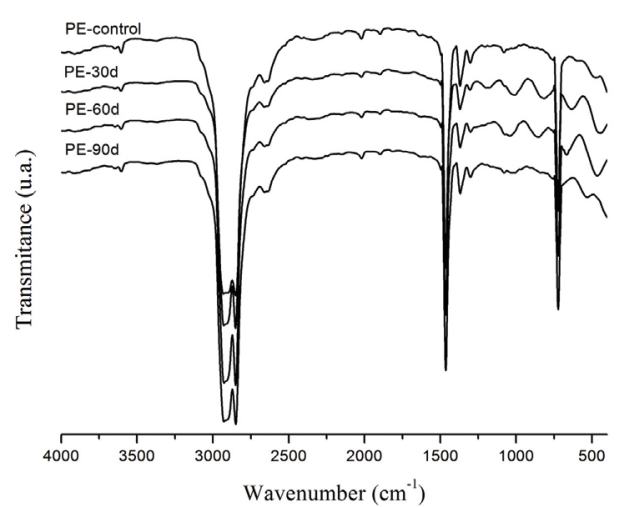

(a)

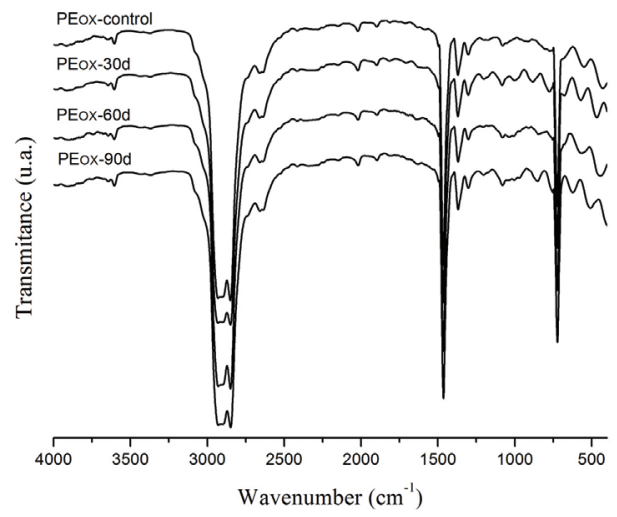

(c)

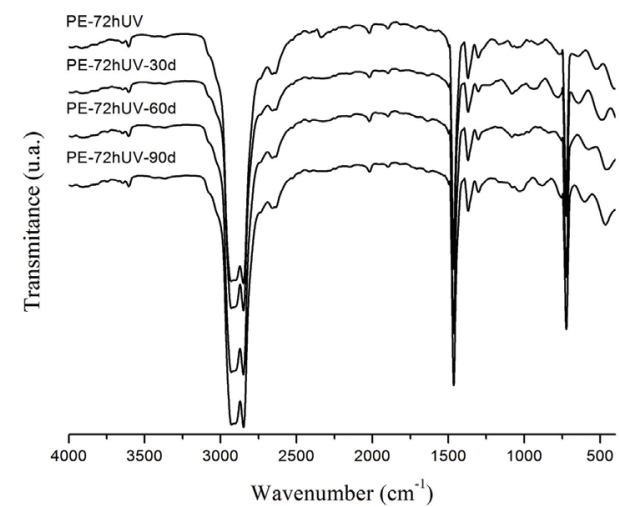

(b)

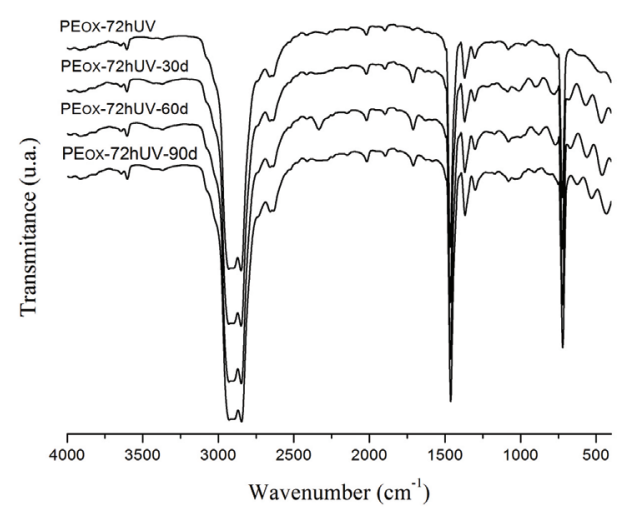

(d)

Figure 6. FTIR spectra of (a,c) PE and $\mathrm{PE}_{\mathrm{OX}}$ samples after 30, 60 and 90 days in simulated soil, (b,d) PE and $\mathrm{PE}$ oX samples after 72 hours of exposure in accelerated aging and after 30,60 and 90 days in simulated soil. 
exposures are showed in Figure 6. In the spectra of nonoxidized and pre-oxidized PE samples, Figures $6 \mathrm{a}$ and $6 \mathrm{~b}$, respectively, any change in chemical structure was observed after exposure in simulated soil during 30, 60 and 90 days, proving that polyethylene degraded very slowly without pro-oxidant. The structural analysis of the pre-oxidized $\mathrm{PE}_{\mathrm{OX}}$ samples (Figure 6d), aging during 72 hours, initially any oxidation was observed, however, after the exposure in simulated soil was possible to identify the formation of a band between 1714 and $1740 \mathrm{~cm}^{-1}$, characteristic of $\mathrm{C}=\mathrm{O}$ bond (carbonyl), indicating formation of oxidation product. These absorption bands were related to the vibrational stretching of ketone $\left(1715 \mathrm{~cm}^{-1}\right)$ and aldehydes and/or esters groups $\left(1733 \mathrm{~cm}^{-1}\right)^{11,28}$. For this sample, it was observed increase intensity in carbonyl peak and relevant CI seen in the FT-IR spectrum of Fig. 5d, after 30 days exposure in simulated soil, and a decreased in CI after 60 and 90 days, attributed to the consumption of carbonyl groups by microorganisms, indicating polymer chain scission by Norrish type I degradation mechanism or by ester formation ${ }^{17}$. On the other hand, the non-oxidized $\mathrm{PE}_{\mathrm{OX}}$ samples (Figure 6c) any change was observed after exposure at simulated soil, proving that initial abiotic oxidation, accelerated aging, and presence of pro-oxidant additive are important factors for determining the rate of the entire process.

\section{References}

1. Kyrikou I, Briassoulis D, Hiskakis M and Babou E. Analysis of photo-chemical degradation behaviour of polyethylene mulching film with pro-oxidants. Polymer Degradation and Stability. 2011; 96(12):2237-2252. http://dx.doi.org/10.1016/j. polymdegradstab.2011.09.001

2. Roy PK, Titus S, Surekha P, Tulsi E, Deshmukh C and Rajagopal C. Degradation of abiotically aged LDPE films containing pro-oxidant by bacterial consortium. Polymer Degradation and Stability. 2008; 93(10):1917-1922. http:// dx.doi.org/10.1016/j.polymdegradstab.2008.07.016

3. Ammala A, Bateman S, Dean K, Petinakis E, Sangwan P, Wong S, et al. An overview of degradable and biodegradable polyolefin. Progress in Polymer Science. 2011; 36(8):10151049. http://dx.doi.org/10.1016/j.progpolymsci.2010.12.002

4. Arnaud R, Dabin P, Lemaire J, Al-Malaika S, Chohan S and Coker, M. Photooxidation and biodegradation of commercial photodegradable polyethylenes. Polymer Degradadation Stability. 1994; 46(2):211-224. http://dx.doi.org/10.1016/01413910(94)90053-1

5. Chiellini E, Corti A and Swift G. Biodegradation of thermallyoxidized, fragmented low-density polyethylenes. Polymer Degradation and Stability. 2003; 81(2):341-351. http://dx.doi. org/10.1016/S0141-3910(03)00105-8

6. Weiland M, Daro A and David C. Biodegradation of thermally oxidized polyethylene. Polymer Degradation and Stability. 1995; 48(2):275-289. http://dx.doi.org/10.1016/01413910(95)00040-S

7. Karlsson S, Ljungquist $\mathrm{O}$ and Albertsson AC. Biodegradation of Polyethylene and the Influence of Surfactants. Polymer Degradation and Stability. 1988; 21(3):237-250. http://dx.doi. org/10.1016/0141-3910(88)90030-4

\section{Conclusions}

The use of polyethylene and pro-oxidants could lead to manufacture biodegradable films in soil environments, although the biodegradation will be at a slow rate. The degradation of pre-oxidized $\mathrm{PE}_{\mathrm{Ox}}$ films was observed after exposure in simulated soil, due to combined effect of photodegradation and pro-oxidant additive. The variation of carbonyl index in pre-oxidized $\mathrm{PE}_{\mathrm{OX}}$ samples during exposure to simulated soil is due to the action of microorganisms on polymer structure that indicate that the process of degradation/biodegradation is beginning. In both samples ( $\mathrm{PE}$ and $\mathrm{PE}_{\mathrm{OX}}$ ) exposed to simulated soil it was observed adherence and colonization of a complex mixture of microorganisms, surface erosion and presence of fruiting bodies and hyphae, characteristics that indicate the biodegradation of the polymer films.

The addition of pro-oxidant additives, when combined with accelerated aging, may be an alternative to propagate the oxidation of polyethylene, but extremely specific conditions were required for the uptake of oxidation byproducts by microorganisms in simulated soil.

\section{Acknowledgements}

The authors acknowledge, Multicolor Indústria e Comércio de Pigmentos LTDA. and Conselho Nacional de Desenvolvimento Científico e Tecnológico (CNPq).

8. Manzur L, Amaral F, Lopes RVV, Schneider ALS and Pezzin APT. Avaliação da degradação em solo de embalagens plásticas oxidegradáveis. In: 10th Congresso Brasileiro de Polímeros; 2009; Foz do Iguaçu, Brasil. Available from: <http://www. ipen.br/biblioteca/cd/cbpol/2009/PDF/643.pdf>. Access in: 12/05/2010.

9. Shah A. Biological degradation of plastics: a comprehensive review. Biotechnology Advances. 2008; 26(3):246265. PMid:18337047. http://dx.doi.org/10.1016/j. biotechadv.2007.12.005

10. Romão W, Spinace MAS and Paoli MA. Poli(tereftalato de etileno), PET: uma revisão sobre os processos de síntese, mecanismos de degradação e reciclagem. Polímeros: Ciência e Tecnologia. 2009; 19(2):121-132.

11. Roy PK. Investigating the role of metal oxidation state on the degradation behaviour of LDPE. Polymer Dagradation and Stability. 2009; 94(7):1033-1039. http://dx.doi.org/10.1016/j. polymdegradstab.2009.04.025

12. Aboulkas A, Harfi KE and Bouadili AE. Thermal degradation behaviors of polyethylene and polypropylene. Part I: Pyrolysis kinetics and mechanisms. Energy Conversion and Management. 2010; 51(7):1363-1369. http://dx.doi. org/10.1016/j.enconman.2009.12.017

13. Lucas N, Bienaime C, Belloy C, Queneudec M, Silvestre F and Navasaucedo JE. Polymer biodegradation: Mechanisms and estimation techniques. Chemosphere. 2008; 73(4):429442. PMid:18723204. http://dx.doi.org/10.1016/j. chemosphere.2008.06.064

14. Jakubowicz I. Evaluation of degradation of biodegradable polyethylene (PE). Polymer Degradation and Stability. 2003; 80(1):39-43. http://dx.doi.org/10.1016/S0141-3910(02)00380-4

15. Dalmolin E, Ojeda TFM, Camargo F and Forte MMC. Avaliação da degradação de Poliolefinas contendo aditivos 
pró-degradantes. In: 17th Congresso Brasileiro de Engenharia e Ciência dos Materiais; 2006; Foz do Iguaçu, Brasil. Available from: <http://www.metallum.com.br/17cbecimat/ resumos/17Cbecimat-404-004.pdf $>$. Access in: 03/03/2010.

16. Amaral F, Mazur LP, Lopes RVV, Pezzin APT and Schneider ALS. Estudo da degradação de embalagens plásticas oxidegradáveis expostas ao envelhecimento acelerado. In: 10th Congresso Brasileiro de Polímeros; 2009; Foz do Iguaçu, Brasil. Available from: <http://www.ipen.br/biblioteca/cd/ cbpol/2009/PDF/463.pdf>. Access in: 14/04/2010.

17. Konduri MKR, Anupam KS, Vivek JS, Kumar DBR and Narasu ML. Synergistic effect of chemical and photo treatment on the rate of biodegradation of high density polyethilene by indigenous fungal isolates. International Journal of Biotechnology and Biochemistry. 2010; 6:157-174.

18. Koutny M, Amato P, Muchova M, Ruzicka J and Delort AM. Soil bacterial strains able to grow on the surface of oxidized polyethylene film containing prooxidant additives. International Biodeterioration \& Biodegradation. 2009; 63(3):354-357. http://dx.doi.org/10.1016/j.ibiod.2008.11.003

19. Fontanella S, Bonhomme S, Koutny M, Husarova L, Brusson JM, Courdavault JP, et al. Comparison of the biodegradability of various polyethylene films containing pro-oxidant additives. Polymer Degradation and Stability. 2010; 95(6):1011-1021. http://dx.doi.org/10.1016/j.polymdegradstab.2010.03.009

20. Albertsson AC, Erlandsson B, Hakkarainen M and Karlsson S. Molecular weight changes and polymeric matrix changes correlated with the formation of degradation products in biodegraded polyethylene. Journal of Environmental Polymer Degradation. 1998; 6(4):187-195. http://dx.doi. org/10.1023/A:1021873631162
21. Yamada-Onodera K, Mukumoto H, Katsuyaya Y, Saiganji A and Tani Y. Degradation of polyethylene by a fungus, Penicillium simplicissi- mum YK. Polymer Degradation and Stability. 2001; 72(2):323-327. http://dx.doi.org/10.1016/ S0141-3910(01)00027-1

22. American Society for Testing and Materials - ASTM. G16003: standard practice for evaluating microbial susceptibility of nonmetallic materials by laboratory soil burial. ASTM; 2003.

23. American Society for Testing and Materials - ASTM. D123804c: standard test method for melt flow rates of thermoplastics by extrusion plastometer. ASTM; 2004.

24. American Society for Testing and Materials - ASTM. D150503: standard test method for density of plastics by the density gradient technique. ASTM; 2003.

25. American Society for Testing and Materials - ASTM. G154-00: standard practice for operating fluorescent light apparatus for uv exposure of nonmetallic materials. ASTM; 2000.

26. Barnett HI and Hubter BB. Ilustrated genera of imperfect fungi. New York: Mac Millan Publish Company; 1972.

27. Lacaz CS, Porto E, Vaccari EMH and Melo NT. Guia para identificação: fungos, actinomicetos e algas de interesse médico. Sarvier; 1998.

28. Gulmine JV. Degradation profile of polyehtylene after artificial accelerated weathering. Polymer Degradation and Stability. 2003; 79(3):385-397. http://dx.doi.org/10.1016/ S0141-3910(02)00338-5

29. Tamada J, Lauger R. Erosion kinetics of hydrolytically degradable polymers. Proceedings of the National Academy of Sciences. 1993; 90(2):552-556. http://dx.doi.org/10.1073/ pnas.90.2.552 